\title{
LO GROTESCO RECURSO PARA LA SATIRA POLITICA EN DONA PERFECTA
}

\author{
Luis Lorenzo-Rivero*
}

En abril de 1876, Galdós concluyó Doña Perfecta que pertenece a las Novelas de la primera época. Las opiniones que desde Clarín hasta el presente se han dado sobre ella son numerosas y muy variadas. Entre los críticos de los últimos treinta años hay quien, como José F. Montesinos, la considera un libro extraño y repelente por tratarse de reproducciones "demasiado fieles de objetos odiosos" y una de las novelas más defectuosas de su autor." Por el contrario, Joaquín Casalduero la tiene como la obra maestra de la primera época, Ignacio Elizalde como una novela cuyo tema central es el problema religioso y con unos personajes bien observados de la realidade, mientras que Ricardo Gullón entiende que el espacio narrativo y el espacio histórico coinciden, constituyendo el problema central de la narración. ${ }^{2}$ Estosy otros galdosistas parecen coincidir más al decir que es uno de sus libros más traducidos, y que constituye un documento imprescindible para la comprensión de ciertas realidades de la Espana del momento. En ella Galdós combate el fanatismo intransigente, la religiosidad mal entendida, el estancamiento de la sociedad y la mezcla de lo eclesiástico con los interesses personales y politicos. ${ }^{3}$

Ese aspecto de Doña Perfecta como símbolo de las dos Espanas en conflicto irreconciliable es el que interesa en este estudio. Se intenta presentar el dolor de Galdós ante el enorme drama existente entre la España sofiada y la de todos los días, su deseo de ahondar la mirada en el pueblo espanol también mediante el recurso de lo grotesco. Este problema, tal como se presenta en esta novela, no sólo atane a la sociedad de aquel tiempo sino que toma "un carácter universal y eterno en el contexto espaffol". 4 El conflicto ideológico de Doña Perfecta consiste en oponer progreso y ciencia a la europea a conservadurismo y clericalismo ibérico, mundos que intentaba unificar, pero fue imposible. Aunque la acción se sitúa en 1875, según María Pilar Aparici, ${ }^{5}$ los acontecimentos que se satirizan corresponden al período de 1868 hasta la publicación de la obra. 1875 fue el affo de la Restauración, 
que para Martínez Campos ofrecía a la nación esa bandera de una monarquia necesaria para poner fín a la guerra carlista Efectivamente, la proclamación de Alfonso XII y su reconocimiento por Cabrera fueron dos golpes mortales para el carlismo. Los políticos de la Restauración eran, sin embargo, hombres de viejo historial, los cuales se dispusieron a gobernar con don Alfonso igual que lo habían hecho con su madre, Isabel II, con don Amadeo, con la primera República y con la Regencia del duque de la Torre.

Después del viaje a París, descubriendo a Balzac, Flaubert y Dickens, y después de haber visto el efecto de algunos avances científicos en la literatura de la época, Galdós quedó planamente metido en el nuevo movimiento narrativo. Entonces, como muy acertadamente explica Miguel Enguídanos estudiando a otro autor: "[...] lo grotesco de su visión de la vida espaffola emanaba de su conciencia de que la realidad histórica y social de España era aún

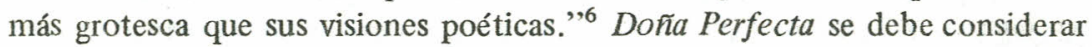
en este sentido un preludio de la serie final de los Episodios nacionales, donde da su visión definitiva de la España de esta época. En ella ha plasmado su idea del país en forma de símbolos, consciente, igual que antes Larra, de que España no marchaba al paso de los demás pueblos del occidente. Los personajes de la novela, tales como Caballuco, Jacinto y María Remedios se hacen monstruosos al contemplarlos desde un punto de vista que no es el que les conviene, ocurriendo algo similar con la toponimia. Como escritor que se dirige al mundo moderno preocupado por su monstruosidad, Galdós necessitaba de alguna manera el recurso de lo grotesco. Ahora bien, aunque sea fácilmente recognoscible y hasta descriptible, lo grotesco resulta difícil de definir o explicar. Las definiciones de Philip Thomson, de Wolfgang Kayser, de Kanneth Burke y otros para el presente son incompletas e inadaptables al concepto de grotesco en la obra galdosiana. Su recurso grotesco: "[...] is decoratively self-sufficient and functional at the same time."7 Por eso, aquí resulta más práctico hablar de elementos grotescos en Doña Perfecta.

En esta novela la ciudad de Orbajosa representa la Espafia que más le dolra a Galdós, o sea, el conservadurismo y fanatismo socio-político. De ahí que en el capítulo II diga que su nombre es corrupción de Urbs augusta, es decir, símbolo de decadencia, que parece un muladar y que es una ciudade dominada por la autoridad eclesiástica, no civil, una ciudad episcopal. Su ubicación, que no se halla cerca ni lejos de Madrid, ni al norte ni al sur, ni al este ni al oeste, sino que está en todas partes donde se encuentren los españoles, proyecta también la inclusión de todos los pueblos espanoles. Sus alrededores resultan horriblemente desolados. En primer lugar, el tren pasa a considerable distancia de la ciudad y para en un desolado y grotesco villorrio, cuyo nombre de Villa-horrenda viena a ser el epíteto que lo califica más exactamente. Los nombres de otros sitios inmediatos resultan grotesca- 
mente irónicos. Así, denomina Valleameno a un paraje de aspecto árido y de negro paisaje; Villarrica es el apelativo de um pueblucho de adobes localizado en un llano esteril; Valdeflores es el calificativo atribuido a un barranco pedregoso, donde ni cardos crecen; etc. Pero lo sumo de lo grotesco lo constituye Orbajosa, que se presenta de súpito a los ojos de Pepe Rey como:

[...] apiñado y viejo caserío asentado en una loma, del cual se destacaban algunas negras torres y la ruinosa fábrica de un despedazado castillo en lo más alto. Un amasijo de paredes deformes, de casuchas de tierra pardas y polvorosas, como el suelo, formaba la base, con algunos fragmentos de almenadas murallas, a cuyo amparo mil chozas humildes alzaban sus miserables frontispicios de adobes, semejantes a caras anémicas y hambrientas que pedían una limosna al pasajero. [...] Los repugnantes mendigos que se arrastraban a un lado y otro del camino pidiendo el óbalo del pasajero ofrećan lastimoso espectáculo.

Esta ciudad, lo mismo que todas las zonas rurales alejadas de las vías de comunicación más importantes, continuó siempre en su letargo. Los españoles carecían, en su mayoría, de una preparación intelectual en consonancia con las exigencias de la época. Incluso la burguesía exhibía una mentalidad anticuada, comparándola con la de esta clase en el resto de Europa. De ahí que Galdós complete en otra parte la descripción de Orbajosa, España, en estos términos:

Además de esto, la patria de los Polentinos, como ciudad muy apartada del movimiento y bullicio que han traído el tráfico, los periódicos, los ferro-carriles y otros agentes que no hay para qué analizar ahora, no gustaba que la molestasen en su sosegada existencia.

Siempre que se ofrecía coyun tura propicia, mostraba viva repulsión a someterse a la autoridad central, que, mal o bien, nos gobernaba; [...] (467).

Las últimas líneas de la cita atacan al carlismo, pero en el párrafo siguiento lo hace de forma más expresa al afirmar que Orbajosa tenía "abolengo faccioso". Las dos Espanas en ese momento se hacen más diferenciadas e irreconciliables. El pronunciamiento de 1868 tuvo sus bases en una conjunción de factores: las crisis económicas de 1866 y 1868, las contradicciones internas de un régimen que se fue deteriorando paulatinamente y la ausencia de personalidades capaces de salvár al régimen. González Bravo no significaba la autoridad, sino la fuerza. Los sucesos de los estudiantes fueron un drama humano, que con Prim señalaron el final. Sin participar directamente en esos acontecimientos, los carlistas salieron favorecidos. Entonces comenzó a vérseles como una posible solución para Espafia, sobre 
todo, al considerar que el mejor sistema para el país era el monárquico, sin encontrar un rey. Como muy bien establece José Ramón Barreiro Fernández, dos fueron los partidos con posibilidades de convertirse en 1868 en un partido de masas: el republicano y el carlista. ${ }^{9}$ Ambos fracasaron en su objeto.

Semejante a 1840 , el pronunciamiento de 1868 trajo la oligarquía militar, restableciendo Prim la monarquía. Su obra perduró veintisiete meses. El seis de junio de 1869 se proclamó la Constitución, que fue acatada, pero no aceptada, por la minoría republicana y rechazada por los tradicionalistas. La muerte de Prim, acaecida el treinta de diciembre de 1870, dejaba abandonado a su suerte al nuevo rey don Amadeo con un dudoso porvenir, quien se encontró con un país políticamente desgarrado y contra él. ${ }^{10} \mathrm{La}$ antipatía por el rey fomentó alianzas tan peregrinas como la de carlistas y federales. En febrero de 1873 se proclamó la República, propagándose al mismo tiempo la guerra carlista que adquirió una violencia salvaje. El pretendiente llegó a dominar toda Vizcaya rural. A esa Espaffa fanática, ultraconservadora y atrasada se oponía la Espana oficial, la que significaba para el carlismo el ateísmo simbolizado por Pepe Rey:

- Mi sobrino no es mi sobrino, mujer; es la blasfemia, el sacrilegio, el ateísmo, la demagogia...

[...]

Mi sobrino, por una serie de fatalidades, que son otras tantas pruebas de los males pasajeros que a veces permite Dios para nuestro castigo, equivale a un ejército, equivale a la autoridad del Gobierno, equivale al alcalde, equivale al juez; mi sobrino no es mi sobrino: es la nación oficial, Remedios; es esa segunda nación, compuesta de los perdidos que gobiernan en Madrid, y que se ha hecho dueña de la fuerza material; $[\ldots](491)$

Galdós tampoco estaba conforme con esta otra Espana oficial de la República y de la Restauración, la cual desconocía el auténtico liberalismo, reduciéndolo a un falso progreso. El adoptó la actitud de europeización como único medio de modernización y como elemento unificador de su fragmentada nación política, religiosa y socialmente. Lo que más desesperaba al escritor es que aquellos necios espafoles se oponían al cambio: "Lo que principalmente distinguía a los orbajonenses del Casino era un sentimiento de viva hostilidad hacia todo lo que de fuera viniese." (441) El clero conservador, sobre todo el carlista, era el que instigaba esta oposición a las ideas de fuera, por heréticas, y a la unión de la nación, rechazando el gobierno central: "El cura nos predicó el domingo tantas cosas altisonantes sobre las heregías y ofensas a la religión que hacen en Madrid..." (480). Esto muestra palpablemente que el novelista condenaba ese mal uso del catolicismo 
como pretexto para la preservación de abominables prácticas políticosociales, sirviendo con frecuencia de cobertura a vicios detestables que nada tenían que ver con la religión. Como muy acertadamente afirma José F. Montesinos: "En España se va a dar la paradoja de que una religión católica, es decir, universal, no sea sino un modo de preservar la inmutabilidad tribal, la de los clanes más intratables que puedan imaginarse."11 Galdós en Doña Perfecta considera más las causas del fanatismo que las consecuencias, siendo la religión la que más sale perdiendo con prácticas que recuerdan más cultos paganos, o un grotesco teatro de muffecos, que el símbolo del dogma cristiano:

\begin{abstract}
- No puedo resistir - añadió Pepe - aquellas imágenes charoladas y bermellonadas, tan semejantes, perdóneme Dios la comparación, a las munfecas con que juegan las niñas grandecitas. ?Qué puedo decir de los vestidos de teatro con que las cubren? [... ] Los mamarrachos y las aberraciones del gusto, las obras grotescas con que una piedad mal entendida llena las iglesias, también cumplen su objeto; pero éste es bastante triste: fomentan la superstición, enfrían el entusiasmo, obligan a los ojos del creyente a apartarse de los altares, y con los ojos se apartan las almas que no tienen fe muy profunda ni muy segura. (440-41)
\end{abstract}

Ya queda indicado que en cierta medida los personajes de Doña Perfecta son símbolos que encarnan actitudes de grupos sociales con diversidad de tendencias políticas. Así Caballuco, descrito grotescamente como un centauro, resulta, en palabras de Ricardo Gullón, "una mala bestia". ${ }^{12}$ Galdós lo caracteriza con las notas del salvaje jefe de partida carlista, enemigo mortal de todo otro tipo de gobierno, a las órdenes de la no menos facciosa dona Perfecta. Esta apoya al pretendiente para defender sus intereses de hidalga fanática colaboradora del clero, que a su vez defiende similares intereses materiales. Esas partidas se estaban levantando en todo el país, siendo las de Orbajosa fomentadas por dona Perfecta con don Inocencio, el canónigo. Por eso su sobrino, Pepe Rey, cuando llega el ejército de Madrid ataca su actitud y acciones en estos términos: 'Yo no soy militar. No haré más que aplaudir cuando vea extirpados para siempre los gérmenes de guerra civil, de insubordinación, de discordia que existen aquí para vergüenza de nuestra época y de nuestra patria." (471) La guerra entró pronto en una espiral de violencia tanto por parte de los facciosos como por parte del gobierno. Todos cometieron asesinatos, incendios, juicios sumarísimos, cortes de orejas a los considerados espías, etc. En la novela ese espíritu de violencia carlista lo simboliza Caballuco, quien incluso lo refleja en su grotesca fisonomía: 
Todos miraron hacia la puerta, donde apareció la imponente figura del centauro, serio, cejijunto, confuso al querer saludar con amabilidad, hermosamente salvaje, pero desfigurado por la violencia que hacía para sonreir urbanamente, y pisar quedo y tener en correcta postura los hercúleos brazos. (459)

Su condición de carlista viejo le impulsaba a la lucha en esta tercera guerra, a la que se lanzó empujado por dona Perfecta y don Inocencio. Incluso obtuvo una victoria sobre el brigadier Batalla, que hace recordar la carlista de 1873 en Eraul con el subsiguiente control de casi toda Vizcaya rural. Este matón disparó la noche de la fuga a las ordenes de la airada doña Perfecta sobre su sobrino y lo mató.

A ese espíritu carcunda carlista pertenece también el abogadillo Jacinto, defensor por interés propio de la Espana actual, que estaba en manos de la intransigencia y del fanatismo, para apoderarse de ella y asegurar su bien estar personal en el futuro. Por eso su madre, temerosa del triunfo del espíritu moderno europeísta, azuza a su tío don Inocencio a que actúe contra lo de fuera con estas desesperadas palabras: "Puesto que mi querido hijo ha de ser siempre un pelagatos, séalo en buena hora. Los pleitos escasean; bien pronto llegar é el día en que lo mismo será la abogacía que nada. [...] Llegará un día, senor don Inocencio, en que mi pobre hijo no tendrá una almohada sobre que reclinar la cabeza". (497) El joven era un producto de aquella desastrosa Universidad espanola. Galdós ya lo había calificado grotescamente en otro lugar de mosquito, que equivale a plaga, peste. Lo hace de nuevo también por boca de las Troyas:

Dibieron ustedes prever que Jacinto las vería desde su templo del saber - dijo Tafetán.

- Don Nominativo es amigo nuestro - replicó una de ellas -. Desde su templo de la ciencia nos dice a la calladita mil ternezas, y también nos echa besos volados. (455)

Es obvio que aquí lo llama pedante, ignorante ingreído y servil, moviéndose, cual títere, a la voluntad de su tío y de doña Perfecta.

El sistema judicial estaba plagado de corrupción y brutalidad en la triste Espana de aquella época. Por una parte, los jueces solfan ser personas inexpertas, de ridícula presunción, ignorantes, engreídas y sin escrúpulos, que ejercian las funciones más delicadas y difíciles de la sociedad. Tal acontece con el juez de Orbajosa satirizado por Galdós: "El juez era un mozalbete despabilado, de estos que todos los días aparecen en los criaderos de eminencias, aspirando, recién empollados, a los primeros puestos de la Administración y de la Política. Dábase no poca importancia, y hablando de sí mismo y de su juvenil toga, parecía manifestar enojo porque no le hubieran he- 
cho de golpe y porrazo presidente del Tribunal Supremo". (444) A eso añ-adase la falta de ética e integridad, poniendo todo su valer al servicio de la causa por sus propios interesses. Así su juzgado resulta un teatro en el que se cometen horrendas injusticias, como los abusos contra Pepe Rey: "Pasaba el joven largas horas del día en el Juzgado dando declaraciones, contestando a preguntas y a preguntas, y cuando a su casa se retiraba, fastigado y colérico, veŕa aparecer la afilada y grotesca carátula del escribano, que le traía regular porción de papel sellado de horribles fórmulas... para que fuese estudiando la cuestión". (447) Esa carnavalesca administración de justicia no para ahi, sino que hasta vienen en tropel escribano, procurador, perito agrónomo, alguacil y otros a citarle a casa de su tía dona Perfecta, verdadera instigadora del bochornoso proceso. Entonces el impotente joven: "Entregó su cuerpo y su alma a los sayones, que esgrimieron horribles hojas de papel sellado, mientras la víctima, elevando los ojos al Cielo, decía para sí con cristiana mansedumbre: 'Padre mío, ?por que me has abandonado'?" (450)

En conclusión, sin negar ni rechazar las mencionadas opiniones de $\tan$ distinguidos galdosistas sobre esta novela, aquí se ha tratado de implementar la opinión de que en ella Galdós satiriza también la España conservadora y fanática para servirle de viva lección para el futuro, con el deseo de que se europeizase. Para conseguirlo ha utilizado, además de los medios que otros han explicado, el recurso de lo grotesco, procedimiento frecuente en otras obras satíricas suyas. Con ello parece afirmar que Espana era un país sin constituirse todavía, condenando a todos los que tuvieron la culpa del drama español.

\section{NOTAS:}

${ }^{1}$ Véase José F. Montesinos, Galdós, 22. ed. (Madrid: Editorial Castalia, 1972), I, págs. 175-178.

${ }^{2}$ Véanse Joaquín Casalduero, Vida y obra de Galdós, 2a ed. (Madrid: Editorial Gredos, 1961), pág. 53; Ignacio Elizalde, Pérez Galdós y su novelistica (Bilbao: Publicaciones de la Universidad de Deusto, 1981), págs. 147-161; Ricardo Gullón, Técnicas de Galdós (Madrid: Taurus Ediciones, 1970), pág. 26.

${ }^{3}$ Véase Gustavo Correa, El simbolismo religioso en las novelas de Pérez Galdós (Madrid: Editorial Gredos, 1974), pág. 35.

${ }^{4}$ María Pilar Aparici Llanas, Las novelas de tesis de Benito Pérez Galdós (Barcelona: C.S.I.C., 1982), pág. 44.

${ }^{5}$ Aparici Llanas, págs. 45-46. 
${ }^{6}$ Miguel Enguídanos, Fin de siglo. Estudios literarios sobre el pertodo 1870-1930 en España (Madrid: Ediciones José Porrúa Turanzas, 1983), pág. 37

7 John W. Kronik, "Galdós and the Grotesque", Anales Galdosianos, Anejo, (1976). pág. 49.

${ }^{8}$ Benito Pérez Galdós, Obras completas. Novelas, Introducciones de Federico Carlos Sainz de Robles, 1a ed. (Madrid: Aguilar. 1970), I, pág. 421. En adelante, las referencias a esta novela serán a esta edición.

${ }^{9}$ Véase José Ramón Barreiro Fernández, El carlismo gallego (Santiago de Compostela: Pico Sacro, 1976), pág. 193.

${ }^{10}$ Véase Tristán La Rosa, España contemporánea. Siglo XIX (Barcelona: Ediciones Destino, 1972), pág. 284 y ss.

${ }^{11}$ Montesinos, pág. 175.

${ }^{12}$ Gullón, pág. 31 .

(*) Department of Languages

University of Utah

153-155 Orson Spencer Hall

Salt Lake City, Utah 84112

USA. 